\title{
Erratum
}

\section{Fetal Diagnosis}

awl' Therapy

In the paper 'A Rare Cause of Fetal Ascites: A Case Report of Günther's Disease' (Fetal Diagn Ther 1999;14:257-261) the 6th author should read K. Massri.

\section{KARGER}

Fax +41613061234

E-Mail karger@karger.ch

www. karger.com (c) 2000 S. Karger AG, Basel

Accessible online at:

www. karger.com/journals/fdt 